\title{
REINTERPRETASI KONSEP BIDAH MENUJU ISLAM TRANSFORMATIF
}

\author{
Nanang Hasan Susanto \\ Institut Agama Islam Negeri (IAIN) Pekalongan \\ Jl. Kusumabangsa No. 9 Pekalongan \\ E-mail: nananghasansusanto8o@gmail.com
}

\begin{abstract}
Reinterpretation the Concept of Heretic toward the Transformative of Islam. This articles aims to reinterpret the concept of heretic (bidah) with a philosophical approach, based on the concept of the transformative of Islam proposed by Moeslim Abdurrahman. The data were collected through library research of the whole concept of heresy, both conservative and moderate then analyzed based on the concept of the transformative of Islam (discourse analysis) based on the conceptual, sociological and anthropological approach. This paper found the need to think philosophically about the concept of heretic, by finding the basic purpose of the revealed of religion, so that there is no contradiction between one doctrine and another. Thus, heresy is no longer as the burden of history of Muslim creativity and innovation, but it is indeed the impetus to find breakthroughs in the settlement of various social problems of society
\end{abstract}

Keywords: the transformative of Islam; reinterpretation; heretic.

\begin{abstract}
Abstrak: Reinterpretasi Konsep Bidah Menuju Islam Transformatif. Tulisan ini bertujuan untuk melakukan reinterpretasi mengenai konsep bidah dengan pendekatan filsafat berdasarkan konsep Islam transformatif yang digagas oleh Moeslim Abdurrahman. Penelusuran data dilakukan dengan kajian pustaka mengenai konsep bidah secara menyeluruh, baik dari kalangan konservatif maupun moderat kemudiandi analisis melalui analisis wacana berdasarkan konsep Islam transformatif dengan menggunakan pendekatan konseptual, sosiologis, antropologis. Tulisan ini menemukan perlunya berpikir secara filosofis mengenai konsep bidah, sesuai dengan tujuan dasar diturunkannya agama yang dimaknai secara kontekstual, sehingga tidak ada pertentangan antara satu ajaran (doktrin) dengan ajaran lainnya. Dengan demikian, bidah tidak lagi menjadi beban sejarah yang menghalangi kreativitas dan inovasi umat Islam, tapi justru menjadi pendorong untuk menemukan berbagai terobosan brilian dalam memecahkan berbagai problem sosial masyarakat.
\end{abstract}

Kata kunci: Islam transformatif; reinterpretasi; bidah.

\section{Pendahuluan}

Agama merupakan salah satu fakta sosial non material yang banyak menyita perhatian para sarjana, khususnya pada bidang kajian sosial. ${ }^{1}$

1 Agama sebagai salah satu fakta sosial nonmaterial pertamakali disampaikan oleh Emile Durkheim. Selanjunya, Durkheim lebih tertark pada fakta sosial non material, ketimbang fakta sosial material (birokrasi, hukum dsb). Berkaitan dengan relasi anta agama dan masyrakat, melalui terakhirnya, The Elementary Forms of Religious Life, Durkheim mengatakan, bahwa masyarakatlah yang menentukan sesuatu bersifat sakral, dan lainnya bersifat profan. Selanjutnya, Durkheim mengatakan, bahwa masyarakat dan agama adalah satu dan sama. Agama adalah cara masyarakat memperlihatkan dirinya sendiri dalam bentuk fakta sosial non material. Lihat George Ritzer dan Douglas J. Goodman, Teori Sosiologi Modern, Terj. Aliman, (Jakarta: Kencana, 2007), Cet. ke-4, h. 23
Pandangan para sarjana tentang agama kaitannya dengan masyarakat bersifat distingsif. Ada yang melihatnya secara positif dan optimis, namun ada juga yang mengatakan kalau agama sebagai penghalang bagi kemajuan peradaban dengan sifatnya yang dogmatis dan anti perubahan².

Diantara pakar yang memandang positif dan optimis terhadap agama adalah Talcot Parson. Dia mengatakan, agama berperan secara kultural dalam pembentukan kesadaran dan hati nurani masyarakat. Peter L. Berger menambahkan, agama sebagai institusi yang berurusan dengan realitas

${ }^{2}$ Lihat Komaruddin Hidayat, "The Failures of Social Religious Roles" in Dialogue of Muslim Scholars to Realize One Religious Community, (Jakarta: UGM Yogyakarta-IFIS, 2010), h. 160 
suci dan mengatasi dimensi waktu. Karenanya, agama diibaratkan sebagai tudung suci yang melindungi manusia dari kelemahan eksistensialnya yang dilambangkan dengan kematian. Bagi Berger, Agama merupakan usaha murni dari masyarakat untuk membangun kosmos suci.Selanjutnya Weber mengatakan, bahwa agama memiliki fungsi sosial, yakni memberi acuan makna bagi manusia untuk mendekati dunia dan masyarakat ${ }^{3}$

Di sisi yang lain, agama seringkali digugat perannya karena dianggap sebagai penghambat dalam mewujudkan peradaban yang menjunjung tinggi prinsip kemanusiaan dan keadilan. $M$. Zainuddin mengatakan, bahwa dalam kehidupan sehari-hari, pemeluk agama seringkali terjebak kepada sifat individualis dan hanya terfokus kepada kehidupan beragamanya saja, melalui doktrin suci, berbagai ritual agama dan lain-lain,sehingga abai terhadap realitas sosial dimana dia hidup. ${ }^{4}$ Karena keberadaannya yang membuat masyarakat abai terhadap problem sosial berupa sistem kerja produksi, Karl Marx juga mengkritik agama sebagai candu yang meninabobokan masyarakat dari persoalan sosial yang sejatinya dihadapi oleh masyarakat tersebut. ${ }^{5}$ Selain itu, August D Comte dengan hukum tiga tingkatannya, yang mengatakan bahwa perjalanan dunia, bahkan masyarakat dimanapun akan melalui tahap perkembangan pemikiran evolutif dari teologis, menuju metafisik, dan terakhir positivistik. ${ }^{6}$ Dalam teorinya ini, faktor agama (teologis) dan metafisik, telah menyebabkan kekacauan intelektual, dan karenanya menyebabkan kekacauan sosial. Karenanya, pergolakan sosial baru akan berakhir apabila kehidupan masyarakat sepenuhnya dikendalikan oleh positivisme. ${ }^{7}$ Berkaitan dengan kemajuan ilmu pengetahuan dan teknologi, sehingga membuat masyarakat modern mengalihkan ketergantungan dari Tuhan

3 Lihat Dadan Ridwan, "Model Alternatif Pendidikan Islam Transformatif; Studi Nilai-nilai Pendidikan Islam dalam Tradisi Ambengan pada Peringatan Hari Besar Islam di Desa Brunorejo Purworejo" Jurnal Millah Vol. XIV No. 2 Februari 2015, h. 254

${ }^{4} \mathrm{M}$. Zainuddin, "Plurality of Religion Future Challenges of Religion and Democracy in Indonesia," Journal of Indonesian Islam, Vol. 09, No. 02, Desember 2015, h. 154

${ }^{5}$ Lihat, Frans Magnis Suseno, Pemikiran Karl Marx: Dari Sosialisme Utopis ke Perselisihan Revisionosme, (Jakarta: Gramedia, 1999), h.34

${ }^{6}$ George Ritzer dan Douglas J. Goodman, Teori Sosiologi Modern..., h. 17

7 George Ritzer dan Douglas J. Goodman, Teori Sosiologi Modern..., h. 18 kepada tekhnologi, Nietze dan August Comte pun mengeluarkan statemen kalau Tuhan telah mati (God is Tot atau God is Death!). ${ }^{8}$

Berbagai kritikan terhadap keberadaan agama diatas merupakan persoalan yang harus dijawab kalagan agamawan untuk melakukan tafsir ulang (reinterpretasi) terhadap pemahaman keagamaan, sehingga melahirkan paradigma keagamaan yang lebih progresif. Dalam Islam, berbagai tokoh intelektual mulai bermunculan sebagai upaya untuk menjawab persoalan diatas. Misalnya saja Fazlur Rahman dengan pemikiran Neo-Modernisme Islam (Islam and Modernity), Hassan Hanafi dengan Kiri Islam (al-Yasar alIslâmi), Mohammed Arkoun dengan Re- Thinking Islam, Nashr Hamid Abû Zayd melalui karyanya berjudul "Tekstualitas al- Qur'ân: Kritik terhadap 'Ulûmul Qur'ân (Mahfûm an Nash Dirâsah fî 'llmil al- Qur'ân)", Abdullah. Ahmed An- Naim melalui karyanya berjudul "Dekonstruksi Syari'ah (Toward and Islamic Reformation Civil Liberties, Human Right and International Law). Di Indonesia juga muncul tokoh-tokoh intelektual seperti Harun Nasution, Nurcholis Madjid, dan Moeslim Abdurrahman dengan teologi transformatifnya.

Tulisan ini bertujuan untuk mewacanakan kerangka berfikir filosofis dalam memahami doktrin agama dalam hal ini Islam (baca: Alquran, dan sunah $\mathrm{Nabi}$ ), terutama terkait dengan konsep bidah yang digagas oleh Moeslim Abdurrahman sebagai kekayaan yang turut meramaikan peradaban Islam.

\section{Metodologi}

Penelitian ini adalah merupakan kajian kualitatif yang bersifat penelusuran pustaka mengenai konsep bidah secara menyeluruh, dari berbagai sumber yang merujuk kepada sumber hukum Islam, maupun dari para pemikir Muslim, baik dari kalangan konservatif maupun moderat. Seluruh data konseptual yang terkumpul tersebut

8 Dikatakan Tuhan telah mati, karena peran sakralnya digantikan oleh tekhnologi. Misalnya dulu manusia hanya percaya kepada takdir kapan hujan akan turun, sekarag melalui tekhnologi, manusia mampu membuat hujan buatan. Atau dulu manusia hanya percaya kepada takdir kapan punya anak berikut jenis kelaminnya, sekarang manusia mampu membuat bayi tabung, mampu merumuskan jenis kelaminnya, bahkan mampu menentukan dari keturunan Bapak/ lbu yang mana. Lihat Cecep Sumarna, Revolusi Peradaban; Usaha Mencari Tuhan alam Batang Tubuh Ilmu, (Bandung: Sae, 2008), h. 13 
kemudian dianalisis berdasarkan konsep Islam transformatif Moeslim Abdurrahman, dan tokohtokoh pemikir Islam terkemuka di Indonesia seperti Abdurrahman Wahid dan Budy Munawar Rachman. Dengan demikian, analisis yang dilakukan adalah analisis wacana, melalui pendekatan konseptual, sosiologis dan antropologis.

\section{Konsep Islam Transformatif}

Istilah Islam Transformatif pertama kali dipopulerkan oleh Moeslim Abdurrahman. ${ }^{9}$ Moeslim Abdurrahman sendiri lahir di Lamongan, Jawa Timur pada tanggal 8 Agustus 1947. la meraih gelar sarjana dari Sekolah Tinggi Ilmu Agama Islam Universitas Muhammadiyah Surakarta (UMS), menyelesaikan program master dan doctor di Departemen Antropologi of Illionis Urbana Campaign, Amerika Serika. Sejumlah karya pemikiran telah ditulisnya, seperti Kang Thowil dan Siti Marginal (Pustaka Firdaus, 1995), Islam Transformatif (Pustaka Firdaus 1995), Semarak Islam, Semarak Demokrasi (1997), On Jajj Tourism: In Search of Pitty and Identity in The New Order Indonesia (2000), Islam Sebagai Kritik Sosial (2003), Islam yang Memihak (2005), Suara Tuhan Suara Pemerdekaan (2009).

Menurut Abdurrahman, dalam Islam transformatif, tujuan risâlah Islâmiyah pada intinya adalah bagaimana membawa ide agama dalam pergulatan hidup secara kolektif untuk menegakkan tatanan sosial yang adil, sebagai cita-cita ketakwaan. ${ }^{10}$ Dalam hal ini, yang menjadi persoalan utama adalah bagaimana agama ditafsirkan untuk dapat memihak pada persoalan keadilan, persoalan nasib orang-orang dalam subordinasi sosial, baik melalui rasionalisasi (perumusan makna hidup yang baru), advokasi (dakwah pembelaan), dan kelembagaan (majelis taklim pemberdayaan). Menurut Abdurrahman, agama harus hadir dalam ketiga ranah tersebut. Tapi pada prakteknya, saat ini agama tidak berani mengambil sikap tegas dalam perebutan makna-makna pemerdekaan (tauhid) diantara relasi-relasi kekuatan dan kekuasaan sejarah yang timpang saat ini."

\footnotetext{
9 Lihat Moeslim Abdurrahman, Islam Transformatif, (Jakarta: Pustaka Firdaus, 1997)

10 Moeslim Abdurrahma, Islam Sebagai Kritik Sosial, (Jakarta: Erlangga, 2003), h. vi

"Moeslim Abdurrahma, Islam Sebagai ..., h. vi-vii
}

Pada tataran praktis, persoalan penafsiran agama yang dimaksud Abdurrahman misalnya menyoroti salah satu doktrin Islam yang tidak boleh menunda pembayaran buruh, apalagi sampai keringatnya kering. Menurut Abdurrahman, doktrin ini tidak mewujud pada realitas, terutama dalam iklim kapitalisme dunia yang memeras keringat buruh yang disebut Abdurrahman sebagai "perawan pabrik".12

Tantangan kemanusiaan universal yang harus dihadapi bersama, Islam dan agama lain adalah kemiskinan yang merupakan indikasi paling dekat dengan soal kekufuran, sebagai suatu proses degradasi kemanusiaan. Inilah persoalan besar umat manusia. Karenanya, menurut Abdurrahman, teologi Islam yang benar adalah teologi yang mengarahkan pada tindakan pemberdayaan untuk mengentaskan kemiskinan. ${ }^{13}$

Berkaitan dengan hubungan antara Islam dan ijtihad, menurut Abdurrahman di dalamnya terdapat dua unsur, yakni: pertama Islam sebagai agama yang memberikan kebebasan seluas-luasnya untuk mengembangkan penafsiran Islam, sehingga Islam diterima oleh semua kalangan sebagai kebenaran universal. Kedua, pokok dari pelaksanaan ijtihad itu adalah pesan dasar untuk selalu melakukan amar ma'rûf dan nahiy munkar (menebarkan kebaikan dan mencegah kemunkaran). Dalam konteks itu, Islam dimata Abdurrahman harus ditafsirkan untuk menciptakan keadilan dengan cara memihak kalangan mustadh'afîn (lemah), dan tertindas oleh mesin gilas kapitalisme. ${ }^{14}$

Menurut Moeslim Abdurrahman, makna Islam yang paling murni bukanlah terletak pada rumusan teologisnya, namun justru muncul dalam pergulatan hidup sehari-hari umatnya untuk menegakkan cita-cita keadilan Islam. Disitulah letak perlunya perumusan kembali teologi berdasarkan realitas struktural yang benar-benar hidup dalam kenyataan sehari- hari dan dihadapi oleh kelompok-kelompok masyarakat Indonesia. Dengan begitu, proses antara refleksi teologis dan membaca konstruk sosial yang sedang dijadikan konteks untuk proses emansipatoris menjadi lebih intens. Rumusan teologis yang kemudian diberi nama teologi

\footnotetext{
${ }_{12}$ Moeslim Abdurrahma, Islam Sebagai..., h. 8-13

13 Moeslim Abdurrahman, Islam yang memihak, (PT LKiS Pelangi Aksara, 2005), h. 27-34

14 Moeslim Abdurrahman, Islam yang memihak..., h. 103-110
} 
transformatif ini, menurut Moeslim Abdurrahman memerlukan kerjasama antara para teolog, analisis ilmu sosial dan para tokoh masyarakat untuk memberi fasilitas kepada transformasi sosial. ${ }^{15}$

Moeslim Abdurrahman lebih menekankan teologi Islam transformatif kepada soal kemiskinan dan ketidakadilan, karena menurutnya, arus besar modernisasi dengan ideologi pembangunannya telah menghasilkan eksploitasi dan marjinalisasi terhadap kaum dhu'afa dan mustadh'afîn. ${ }^{16}$ Dengan begitu, Islam transformatif adalah Islam yang membuat distingsi dengan proses modernisasi atau modernitas yang bekerja dengan menghubungkan refleksi teologis dengan pembacaan konstruk masyarakat agar dapat menimbulkan gerakangerakan transformasi sosial. Hal ini karena menurut Moeslim, di dalam proses modernisasi itu banyak orang yang semakin tidak peduli terhadap persoalan perubahan atau proses sosial yang semakin memarginalkan orang- orang yang tidak punya akses dengan pembangunan. ${ }^{17}$

Menurut Budy Munawar Rachman, meskipun substansi gagasannya sudah lama,tapi pemikiran Islam transformatif tergolong sebagai pemikiran baru, yakni menghendaki agar kaum Muslim menciptakan tata sosial-moral yang adil dan egaliter, dalam rangka menghilangkan penyelewengan di atas dunia, fasd fî al- ardl, melalui pertimbangan aspek sosiologis dan ilmu-ilmu sosial. ${ }^{18}$

Sebagaimana yang disampaikan Rachman bahwa substansi gagasan Islam transformatif sebenarnya sudah lama, karena secara doktrinal, Islam merupakan agama transformatif. Misi transformatif Islam sudah muncul sejak zaman Rasulullah Saw. Hal ini dapat dilihat dari misi kerasulan Muhammad Saw yang ditujukan untuk membebaskan manusia dari berbagai hal yang merendahkan martabatnya seperti kemusyrikan, rasa malas, takut, pesimis, lemah kebodohan, dan berbagai keterbelakangan lainnya. Islam yang lahir di tengah komunitas Arab yang sangat eksploitatif, piramidal dan patologis, namun berhasil mengubah sistem sosial tersebut menjadi masyarakat yang berdimensi keadilan, persamaan, saling

\footnotetext{
${ }^{15}$ Moeslim Abdurrahma, Islam Sebagai..., h. 27.

${ }^{16}$ Moeslim Abdurrahma, Islam Sebagai ..., h. 107

${ }^{17}$ Moeslim Abdurrahma, Islam Sebagai..., h. 186

18 Budhy Munawar Rahman, Islam Pluralis: Wacana Kesetaraan Kaum Beriman, (Jakarta:Paramadina, 2001), h. 331
}

menghargai, dan pembebasan. Secara dotrinal, Alquran menyebutkan bahwa keadilan adalah sendi utama dalam masyarakat (Q.S. al-A'râf: [7]:29, Q.S. al-Mâ'idah [5]: 8), membela hak-hak rakyat bawah (Q.S. an-Nisa' [4]:75), dan mengutuk orang yang hidupnya sibuk mengumpulkan harta, namun abai terhadap realitas sosial di sekelilingnya (Q.S. an-Nashr: [104]; 1-4). Selain itu, sebagaimana yang dikemukakan Syafî’i Anwar, misi Islam yang paling utama adalah kemanusiaan. ${ }^{19}$

Menurut Abdurrahman Wahid, setiap agama termasuk Islam pada dasarnya memiliki watak transformatif, yaitu berusaha menanamkan nilainilai yang baru dan mengganti nilai-nilai lama yang dianggap bertentangan dengan ajaranajaran agama. Karenanya, orientasi dan metode yang digunakan transformasi Islam, semuanya diletakkan dalam kerangka memecahkan masalahmasalah yang dihadapi umat manusia, seperti kemiskinan, kebodohan, ketidakadilan, langkanya kepastian hukum, ketimpangan sosial dan lain sebagainya. ${ }^{20}$

Pada kesempatan yang lain, menurut Mansour Fakih, dalam Islam transformatif, prinsip utama Alquran diyakini melawan segala bentuk ketidakadilan, seperti eksploitasi ekonomi, penindasan politik, dominasi budaya dominasi gender, penindasan warna kulit dengan segala bentuknya. ${ }^{21}$ Maghfur menambahkan, bahwa ajaran Islam harus menjadi kekuatan yang membebaskan manusia dan masyarakat dari belenggu kemiskinan, kebodohan, ketidakadilan dan keterbelakangan. ${ }^{22}$

\section{Bidah, Pintu Kreatifitas dan Inovasi Umat Islam}

Dalam kazanah Islam, bidah merupakan lawan kata sunah. Menurut Abu Muhammad Izzudin bin Abdussalam, bidah dipahami sebagai "Fi'lun mâ lam Yu'had fî 'ashri rasûlillâhi Shalla Allâh 'alaihi wa Sallam (mengerjakan sesuatu yang tidak pernah

19 M. Syafi'i Anwar, Pemikiran dan Aksi Islam Indonesia, (Jakarta: Paramadina, 1995), h. 162

20 Abdurahman Wahid, Islam dan Militerisme Dalam Lintas Sejarah, dalam Muslim di Tengah Pergumulan (Jakarta: Lappenas, 1981), h. 101

${ }^{21}$ Mansour Fakih, Teologi kaum Tertindas, dalam spiritualitas Baru: Agama dan Aspirasi Rakyat, (Yogyakarta: Dian 1994), h. 203

${ }^{22}$ Maghfur, dkk, Islam Transformatif. Risalah kerja Intelektual Organik (Pekalongan: STAIN Pekalongan Press, 2012), h. 2 
dikenal (terjadi) pada masa Rasulullah Saw) ${ }^{23}$. Sedangkan kata sunah didefinisikan sebagai Al-Thâriqah al-maslûkah fî al-dîn bi an salakha rasulûllâh ahalla Allâh 'alaihi wa as-Sallâm aw al-salaf al-shalih min ba'dihi (Jalan yang dijalani dalam agama karena biasa dijalani Rasulullah dan oleh orang-orang terdahulu yang shalih, sesudah Rasul Saw wafat) ${ }^{24}$.

Kata bidah secara bahasa (etimologis) memiliki dua kata asal. Pertama Al-bad'u diambil dari fi'il mâdhiy bada'a. Kedua, Al-lbda' yang diambil dari fi'il madhiy, abda'a. Kedua kata tersebut memiliki makna yang sama, yaitu kata yang memiliki makna tumbuhnya sesuatu tanpa adanya contoh sebelumnya, yang diada-adakan, dan merupakan kreasi yang sebelumnya tidak ada ${ }^{25}$.

Kata al-Badi' juga merupakan salah satu asma Allah, karena Dialah yang menciptakan segala sesuatu. Dialah pencipta yang pertama sebelum segala sesuatu ada. Dialah Allah, pencipta yang mengada-adakan sesuatu tanpa contoh terdahulu (mitsal sabiq) ${ }^{26}$. Dalam Alquran surat al-Baqarah [2]: 117, Allah berfirman: "Allah Pencipta Langit dan Bumi". Dengan demikian, secara bahasa, bidah berarti sesuatu kreasi, inovasi, ciptaan yang baru dibuat tanpa ada contoh ciptaan serupa sebelumnya.

Secara istilah (terminologis), para ulama berbeda pendapat dalam mendefiniskan bidah. Secara garis besar, perbedaan tersebut dibagi menjadi dua kelompok, yakni pendapat yang mengatakan, kalau bidah itu ada yang terpuji dan tercela, sedangkan pendapat kedua mengatakan, segala sesuatu yang berbau bidah, tiada kata lain untuk mensifatinya, selain tercela.

\section{a. Pendapat Pertama}

Menurut kelompok pertama, segala sesuatu yang baru setelah masa Rasulullah Saw disebut

23 Abu Muhammad 'Izudin bin Abdussalam, Qawa'id alAhkâm fî Mashalih al-An'âm (Beirut: Dar al-Kutub al-Ilmiyah, tt), h. 172

${ }^{24}$ Muhammad bi Ali bin Muhammad al-Syaukani, Irsyadul Fuhul Juz I (Beirut: Dar al-Fikr, 1992). h. 67

${ }^{25}$ Supani, "Kajian Terhadap Dalil dan Argumen Pendukung Serta Penolak Adanya Bidah Hasanah", Jurnal Penelitian Agama Vol. 9 No.2, 2008. h. 3.

${ }_{26}$ Mujiddu al-Dîn Abu al-Sa'adat bin Muhammad alJaziri ibnu al-Atsir, al-Nihâyah fî Gharib al-Hadits wa al-atsar, (Muassasah isma'iliyan, 1367), Juz 1, h. 106 bidah, baik yang terpuji maupun tercela. Pendukung kelompok ini antara lain Imam AsySyafî'i, al-'Izz bin 'Abdussalâm, al-Qarafî, alGhazâlî, Ibnu al-Atsir, dan Imâm al-Nawawi' ${ }^{27}$.

Sebagaimana diriwayatkan oleh Baihaqi dalam Manaqib al-Syafî̀, bahwa Imam Syafî̀̂ menyatakan:

"Perkara-perkara yang baru itu ada dua macam: Pertama, sesuatu yang baru, yang tidak selaras dengan kitab (al-Qur'ân), Sunnah, atsar dan ljma' disebut Bidah Dhalâlah (sesat). Kedua, sesuatu yang baru, yang selaras dengan kitab (al-Qur'ân), sunnah, atsar, dan ljma' disebut bidah mahmudah/ghairu madzmûmah"28.

'Izzu al-Dîn bin Abdussalâm membagi bidah menjadi lima bagian, sesuai dengan al-ahkâm alsyar'iyyah al-khamsah (lima hukum syariat), yaitu:

1) Bidah wajibah, yaitu bidah yang dilakukan untuk mewujudkan hal-hal yang diwajibkan oleh syara'. Misalnya sibuk mempelajari nahwu, saraf dan ushul fikih (berbagai disiplin ilmu ini belum dipelajari pada masa Rasulullah, sehingga masuk kategori bidah). Berbagai disiplin ilmu ini merupakan alat untuk memahami kalam Allah. Menjaga syariat itu hukumnya wajib, dan upaya penjagaan itu tidak bisa terwujud, kecuali dengan memahami berbagai disiplin ilmu diatas. Oleh sebab itu, belajar berbagai disiplin ilmu diatas juga hukumnya wajib.

2) Bidah Muharromah, yaitu bidah yang bertentangan dengan syara', seperti mazhab Jabbariyah dan Murji'ah.

3) Bidah Mandubah, yaitu suatu kebaikan yang belum pernah dilakukan pada masa Nabi Saw, misalnya melakukan shalat tarawih dengan berjamaah, mendirikan madrasah, dll.

4) Bidah Mubahah, misalnya mushafahah, (berjabat tangan) sesudah shalat shubuh dan ashar, makan makanan yang lezat.

5) Bidah makruhah, yaitu sesuatu yang kurang pantas dilakukan, misalnya, menghiasi masjid dengan hiasan yang belebihan ${ }^{29}$.

${ }^{27}$ Supani, "Kajian Terhadap Dalil..., h. 4

${ }^{28}$ Al-Baihaqi, manaqib al-Syafi'i, (Tahqiq) Al-Sayyid Ahmad Shaqr, (Al-Qahirah: dar al-Turats, tt), h. 468-469

${ }_{29}$ Abu Muhammad 'Izzu al-Din bin Abdussalam, Qawâ'id al-ahkâm fîmashalih al-An'âm, Juz 1 (Beirut: Dar al-Kutub alIlmiyah, tt), h. 173 
Merujuk pendapat Imam Syafî'i yang mengklasifikasikan adanya bidah yang baik (mahmudah) dan sesat (dhalâlah), maka jika disesuaikan dengan uraian Imam 'Izzu al-Din diatas, dapat dipahami bahwa yang termasuk kategori bidah hasanah adalah bidah wajibah, bidah mandubah, dan bidah mubahah. Sedang bidah muharomah dan makruhah termasuk dalam kategori bidah dhalâlah.

Lebih jauh, KH. Muhyiddin Abdusshomad dalam buku Fiqih Tradisionalis, contoh bidah hasanah antara lain adalah khutbah yang diterjemahkan ke dalam bahasa Indonesia,antara lain, (1) membuka suatu acara dimulai dengan membaca basmalah di bawah seorang komando, (2) memberi nama pengajian dengan istilah kuliah shubuh, pengajian ahad pagi atau titian senja, (3) menambah bacaan subhânallâhu wata'âla (yang diringkas dengan Swt) setiap ada kalimat Allah, (4) menambah shallallâhu 'alaihi wa sallâma (yang disingkat Saw) setiap ada kata Muhammad, (5) serta perbuatan perbuatan lainnya yang belum pernah ada pada masa Rasulullah Saw, namun tidak bertentangan dengan inti ajaran Islam ${ }^{30}$.

Selain itu, Syeikh Ja'far Muhammad Ali alBaqiry, mengatakan:

"Ketahuilah, bahwasannya setiap sesuatu yang baru muncul setelah wafat Rasululllah Saw itu bidah. Segala sesuatu yang selaras dengan dalildalil sunah serta kaidah-kaidah yang berlaku atau ketentuan yang didasarkan pada kaidah qiys (mengqiyaskan dengan sesuatu yang selaras dengan dalil sunah dan kaidah yang berlaku), maka itu bidah hasanah. Sedangkan bidah yang tidak selaras dengannya (dalil-dalil sunah serta kaidah-kaidah yang berlaku), maka disebut bidah sayyi'ah dan sesat" ${ }^{31}$.

Pada kesempatan yang lain, Ibnu Al-Atsir dalam kitab Jami' al-Ushul menjelaskan batasan bidah sebagai berikut:

"Jika yang dilakukan itu menyalahi apa yang diperintahkan Allah dan Rasul-Nya, maka dikategorikan bidah yang tercela dan munkar, sedangkan bidah yang sesuai atau berada pada lingkup keumuman apa yang disunahkan

${ }^{30}$ Muhyiddin Abdussomad, Fiqh Tradisionalis, Jawaban Pelbagai Persoalan Keagamaan Sehari-hari (Malang: Pustaka Bayan kerjasama dengan PP Nurul Islam Jember 2005), h. 27

${ }^{31}$ Syeikh Ja'far Muhammad Ali al-Baqiry, Al-Bidah, (Rabithah al-Tsaqofah wa al-‘alaqat al-Islamiyah 1996), h. 146 dan dianjurkan Allah dan Rasul-Nya, maka tergolong bidah yang terpuji" ${ }^{2}$.

Berbagai pendapat yang mereka kemukakan mengenai adanya bidah yang baik (hasanah) ini disandarkan kepada perkataan Umar bin Khattab RA, terkait dengan pelaksanaan shalat tarawih secara berjama'ah; "ni'mat al-bid'atu hadzihi" (sebaik-baik bidah adalah ini) ${ }^{33}$.

Berdasarkan kitab yang dikutip pada perkataan Umar bin Khattab RA diatas, diceritakan bahwa pada awalnya, salat tarawih dilakukan oleh masyarakat Muslim dengan cara yang sama persis seperti yang diakukan pada masa Rasulullah, yakni dilaksanakan hanya pada beberapa malam terakhir Ramadhan dan tidak dilakukan secara berjamaah dengan dipimpin oleh satu orang imam. Namun dengan inovasi yang dilakukannya, setelah masa Umar, pelaksanaan salat tarawih dilaksanakan setiap malam dan dilakukan dengan berjamaah seperti yang sekarang dilakukan masyarakat Muslim.

\section{b. Pendapat Kedua}

Pendapat golongan ini mengatakan, bahwa bidah adalah segala sesuatu yang tidak ada dasar hukumnya dalam syara'. Karenanya, menurut golongan ini, segala bentuk bidah pasti tercela/ madzmumah. Dengan kata lain, golongan ini menolak adanya bidah yang hasanah. Kalangan ulama yang termasuk golongan ini adalah Imam Malik RA, Asy-Syâthibî, Ibnu Hajar al-'Asqalânî, Ibnu Hajar al-Haitamî, Ibnu Rajab al-Hanbalî, Syaikhul Islam Ibnu Taimiyah, dan al-Zarkasyi. Imam Malik bahkan mengatakan: "Barangsiapa membuat bidah dalam Islam, dan dia menyangka bidahnya itu baik, maka berarti dia menuduh Muhammad menghianati/tidak menyampaikan risalah karena Allah telah berfirman: "Pada hari ini telah aku sempurnakan bagimu agamamu"34.

\section{Polemik Seputar Bidah}

Pada dasarnya, kedua golongan yang berbeda dalam menyikapi bidah diatas sama-sama menyandarkan pedapatnya pada hadis. Hanya

${ }^{32}$ Muhammad Ibnu al-Atsir al-Jaziri, Jamî' al-Ushûl fî Ahadits al-Rasul, (Beirut: dar al-Fikr, 1983), Juz. 1 h. 280-281

33 Diriwayatkan oleh Imam Bukhari pada kitab shlat tarawih, bab fadhli man qâma Ramadhâna, juz. 3 . h. 58-59. Juga diriwayatkan olwh Imam Muslim dalam kitab shalat almushafirîn, bab al-taghrîb fî qiyîm Ramadhân, juz. 1, h. 524

34 Imam Malik, dalam Supani, "Kajian Terhadap Dalil ..., h. 5 
saja, mereka berbeda dalam menafsirkan lafaz "kullu" dalam hadis: " kullu bid'atin dhalâlah", sebagaimana hadis yang diriwayatkan oleh Abu Dawud dan Turmudzi dan telah dikutip diatas ${ }^{35}$.

Golongan yang menentang adanya bidah hasanah, dan karenanya menganggap semua bidah itu sesat mengatakan bahwa lafadz kullu pada hadis diatas berlaku umum secara mutlak. Sehingga segala sesuatu yang berbau bidah, tidak ada hukum lain kecuali sesat. Selain itu, mereka juga berpendapat, bahwa agama Islam telah sempurna sebelum wafatnya Rasulullah Saw, sehingga tidak perlu adanya penambahan maupun pengurangan. Dalam hal ini, mereka mengemukakan beberapa dalil:

a. Q.S.al-Mâ'idah [5]: 3,

"Pada hari ini (masa haji wada') orang-orang kafir telah putus asa untuk (mengalahkan) agamamu, sebab itu janganlah kamu takut terhadap mereka dan takutlah kepada-Ku. Pada hari ini telah Kusempurnakan untuk kamu agamamu, dan telah Ku-cukupkan kepadamu nikmat-Ku, dan telah Ku-ridhai Islam itu jadi agama bagimu".

Selain Imam Malik yang RA yang mengatakan bahwa orng yang membuat bidah kemudian menganggap bidahnya itu baik, berarti menuduh Muhammad menghianati (tidak menyampaikan) risalah berdasarkan firman Allah mengenai telah sempurnanya agama (Islam) diatas,Imam Asy-Syathîbî selaku pengikut Imam Malik juga mengatakan, bahwa apa saja yang bukan merupakan agama pada hari itu, maka ia juga bukan termasuk agama pada hari ini.

b. Hadis Nabi yang mengatakan: "kullu bid'atin dhalâlah". Sebagaimana dikutip Abdul Qayyûm Muhammad As-Sahibani, Muhammad bin Shalih Al-'Utsaimin berkata, "Sesungguhnya perkataan beliau, Nabi Saw: "kullu bid'atin dhalâlah", (setiap bidah sesat), merupakan ungkapan yang bersifat umum dan menyeluruh, karena diperkokoh dengan kata yang menunjukkan makna menyeluruh dan umum yang paling kuat, yakni kata "kullu" yang berarti semua. Oleh karena itu, apa saja yang diklaim sebagai bidah hasanah, maka

35 Hadis riwayat Abû Dawûd dan Turmûdzi. hendaklah dijawab dengan dalil itu. Atas dasar itulah, maka tidak ada sedikitpun peluang bagi ahli bidah untuk menjadikan bidah mereka sebagai bidah hasanah ${ }^{36}$.

Berbeda dengan golongan yang menolak adanya bidah hasanah, pendukung bidah hasanah mengatakan bahwa hadis kullu bid'atin dhalâlah sebagai dalil umum yang sudah dikhususkan dengan dalil lain. Oleh karena itu, tidak setiap kullu bermakna seluruh atau semua, ada kalanya berarti sebagian, yaitu ketika ada qarînah (sesuatu yang menunjukkan maksud perkataan), berupa dalil lain yang bersifat khusus. Beberapa argumen bisa diajukan untuk mendukung pendapat ini, baik dari segi balaghah, mantiq, maupun pendekatan kebahasaan.

Menurut kajian ilmu balaghah, kullun tidak selalu berarti semua, adakalanya berarti sebagian. Misalnya yang terdapat dalam Alquran surat alAnbiyâ' [21]: 30:

"Dan apakah orang-orang yang kafir tidak mengetahui bahwasannya langit dan bumi itu keduanya dahulu adalah suatu yang padu, kemudian Kami pisahkan antara keduanya, dan dari air Kami jadikan segala sesuatu yang hidup. Maka mengapakah mereka tiada juga mau beriman?"

Walaupun ayat ini menggunakan kata kullu, namun tidak berarti semua benda yang ada di dunia ini diciptakan dari air. Buktinya adalah Firman Allah Swt berikut ini:

"Dan Dia menciptakan Jin dari nyala api".

Perpaduan kedua ayat diatas memberikan pemahaman kepada kita, bahwa tidak semua yang hidup ini Allah ciptakan dari air. Ada makhluk hidup yang diciptakan Allah dari percikan api. Hal ini berarti kata kullu pada ayat pertama ditakhsish dengan ayat kedua karena ada qarinah/petunjuk tentang pengkhususan makna umum tersebut dari dalil ayat kedua ${ }^{37}$.

Contoh lain terdapat dalam Q.S al-Kahfi [18]: 79:

"Adapun bahtera itu adalah kepunyaan orangorang miskin yang bekerja di laut, dan aku bertujuan merusakkan bahtera itu, karena dihadapan mereka ada seorang raja yang merampas tiap-tiap bahtera".

${ }^{36}$ Abdul Qayyum Muhammad As-Sahibani, Mengapa anda menolak bidah hasanah? (Solo: At-Tibyan, 2003). h. 28

${ }^{37}$ Supani, "Kajian Terhadap Dalil..., h. 9 
Ayat ini menjelaskan bahwa dalam perjalanannya, dihadapan nabi Musa dan nabi Khaidir, ada seorang raja lalim yang suka merampas perahu yang bagus. Sedangkan perahu yang jelek tidak dirampasnya. Makanya, nabi Khidir sengaja merusak perahunya agar tidak dirampas, dan usahanya ini berhasil.

Kata "kullun" disini tidak berarti semua. Karena pada kenyataannya, tidak semua bahtera dirampas oleh raja lalim. Jika kullun diartikan semua, maka nabi Khidir melakukan kesalahan fatal, karena dirusak ataupun tidak, bahtera itu tetap akan dirampas sang raja. Jika nabi Khidir melakukan kesalahan, maka ini bertentangan dengan ayat 82 pada surat yang sama, yakni nabi Khidir menyatakan: "wa mâ fi'latuhu 'an amrî". (dan tidaklah aku melakukan hal itu atas kehendakku sendiri (melainkan atas kehendak Allah).

Bandingkan lafaz kullu dalam firman Allah diatas dengan lafadz kullu dalam hadis Nabi yang mengatakan "kullu bid'atin dhalâlah". Diantara keduanya terdapat kesamaan, baha lafaz kullu tidak mesti diartikan semua tanpa terkecuali, tapi sama-sama memiliki pengecualian.

Untuk memperkuat argumen bahwa lafaz kullu tidak selamanya bermakna semuanya dengan sifatnya yang mutlak, perhatikan hadis Nabi dibawah ini yang membicarakan tentang malu.

Beberapa hadis Nabi tetang malu:

"Malu itu semuanya baik" 38 .

"Malu itu tidak akan datang kecuali membawa kebaikan"39.

Jika kata kullu (semuanya) dalam hadis tersebut dimaknai berlaku umum secara mutlak sebagaimana pendapat golongan penentang bidah hasanah, maka dapat diartikan segala bentuk malu itu membawa kebaikan. Termasuk malu beribadah, malu menuntut ilmu, malu bersedekah, dan lain-lain. Pemahaman seperti ini nampaknya keliru, karena tidak semua malu itu membawa pada kebaikan. Hal ini sebagaimana komentar Siti 'Aisyah yang dibahas Imam Bukhari dalam "Jawahir al-Bukhari":

"Mujahid bin Jubair berkata: Tidak akan pernah dapat menuntut ilmu orang yang pemalu dan orang yang sombong. Siti 'Aisyah berkata:

\footnotetext{
${ }^{38}$ Hadis riwayat Muslim

39 Hadis riwayat Bukhâri Muslim, dari 'Imrân bin Husain
}

Sebaik-baik wanita adalah wanita Anshar, mereka tidak pernah terhalang oleh rasa malu dalam memperdalam agama"40.

Melalui uraiannya ini, Imam Bukhari ingin menjelaskan kepada umat Islam, bahwa sesungguhnya sifat malu yang menghalang-halangi kita untuk menuntut ilmu adalah tercela. Oleh karena itu, tidak semua malu itu baik, apabila ia menghalangi kita untuk berbuat baik, sebagaimana tidak semua bidah itu tercela, apabila bidah itu mendorong pada kebaikan.

Selain itu, nabi Muhammad pada masa kenabiannya tidak pernah menghalang-halangi atau melarang para sahabatnya ketika melakukan sesuatu yang baru (bidah) yang baik (hasanah). Berbagai contoh berikut dapat menjadi argumen kuat pendapat diatas:

a. Bilal bin Rabah setiap kali hadats beliau langsung bersuci. Bilal juga selalu sholat dua roka'at setiap selesai wudu dan sehabis azan. Hal ini beliau lakukan berdasarkan pemikiran beliau sendiri, kreasi dan inisiatifnya sendiri. Tidak ada petunjuk khusus dari Rasulullah Saw. Lalu bagaimanakah respons Rasulullah Saw? Rasulullah Saw memuji Bilal, "Engkau mendahuluiku ke surga wahai Bilal"41

b. Dalam sebuah kisah yang penuh dengan patriotisme, Khubaib bin Adi al-Anshâri melakukan salat dua rakaat sebelum dibunuh oleh orang-orang qurais, hingga akhirnya kematian sahid menjemputnya ditiang salib. Salat yang dilakukan oleh Khubaib bin Adi ini kemudian menjadi tradisi yang dilakukan oleh para sahabat yang dengan tabah menerima kematian oleh kekejaman orang-orang kafir ${ }^{42}$. Salat dua rakaat yang dilakukan oleh Khubaib muncul dari inisiatifnya sendiri, karena beliau beranggapan salat adalah ibadah yang paling utama dan mulia. Beliau ingin akhir hayatnya ditutup dengan salat. Rasulullah Saw tidak pernah memberi petunjuk khusus mengenai hal itu, misalnya Rasulullah Saw memerintahkan "Salatlah dua rakaat sebelum engkau di bunuh oleh orang-orang kafir!".

c. Salah seorang sahabat anshar yang menjadi

\footnotetext{
40 Jawâhirul Bukhari. h. 70-71

${ }^{41}$ Diriwayatkan oleh At-turmûdzi di dalam sunan, al-Hâkîm dalam al-Mustadrok, al-Bayhâqi dalam Syu’abûl imân.

${ }^{42}$ Lihat al-mu'jam al- kabîr at-thabrâni, juga diriwayatkan al-Bukhori dan Ahmad
} 
imam di masjid Quba', setiap kali selesai membaca surat al-fatihah beliau pasti membaca surat al-ikhlâsh, baru kemudian beliau membaca surat yang lain. Jadi surat apapun yang ia baca dalam salat pasti didahului dengan membaca surat al-ikhlâsh. Hingga berita ini sampai kepada Rasulullah Saw. Rasulullah Saw bertanya kepada sahabat yang menjadi imam itu, "Apa yang mencegahmu memenuhi permintaan temantemanmu?, apa yang mendorongmu membaca surat al-ikhlâsh itu setiap rakaat?". Sahabat itu menjawab, "Sungguh aku mencintai surat itu". Lalu Nabi Saw berkata, "Apa yang kau cintai akan membawamu ke surga"43.

d. Qotadah bin Nu'man, sebagaimana diceritakan al-Hafidh ibn Hajar, setiap malam beliau menghabiskan malamnya dengan mengulangulang surat al-ikhlas di dalam sholat hingga masuk waktu subuh. Hal ini kemudian dilaporkan kepada Nabi. Dan bagaimanakah tanggapan Nabi? Rasulullah Saw dengan lembut dan motivasi yang tinggi beliau berkata "Demi Dzat yang jiwaku berada dalam genggamannya, surat al-Ikhlâsh itu sebanding dengan sepertiga al-Qur'ân".

e. Sebelum peristiwa ini terjadi, ketika para sahabat ketinggalan jamaah, mereka akan bertanya sudah rakaat keberapakah Nabi?, kemudian mereka akan takbir dan melakukan gerakan-gerakan yang tertinggal hingga ketika sudah sama gerakan dan rakaatnya baru mereka mengikuti gerakan imam. Sehingga jama'ah terlihat kurang teratur. Ada yang masih berdiri, ada yang masih ruku', ada yang sujud, dan lain sebagainya. Hingga suatu hari datanglah Mu'adz bin Jabal yang terlambat jamaah. Mu'adz bin jabal langsung mengikuti gerakan $\mathrm{Nabi}$, dan setelah salam beliau menambah raka'at yang tertinggal. Hal ini ia lakukan semata-mata karena kecintaannya pada Rasulullah Saw. Beliau tidak mau ketinggalan lebih banyak lagi, beliau ingin gerakannya sama dengan gerakan imam dalam hal ini Rasulullah Saw.Lalu bagaimanakah Rasulullah Saw menyikapi tindakan Mu'adz bin Jabal tersebut, yang sama sekali belum pernah diajarkan oleh Rasulullah Saw. Bahkan berbeda

${ }^{43}$ lihat Fathul Barî al-Hafidh ibnu Hajar dalam bab al-jam'u baina sîratain fî ar- rak'ati dengan sahabat-sahabat yang lain. Rasulullah Saw kemudian berkata, "Sesungguhnya Mu'adz telah membuat satu jalan (cara) baru untuk kalian, lakukanlah seperti yang dilakukan oleh Mu'adz!"'44. Hingga sekarang kita melakukan apa yang dilakukan oleh Mu'adz bin Jabal.

Jika ditelusuri lebih jauh, masih banyak riwayat yang menyebutkan kearifan Nabi dalam merespon positif kreatifitas dan inovasi para sahabatnya. Tidak dapat dibantah, kepemimpinan beliau yang karismatik, dan keberhasilannya dalam mengibarkan bendera Islam di lingkungan Arab dan kemudian dilanjutkan para penerusnya ke seantero dunia, pasti beliau lakukan dengan cara yang bijak, santun, Roûf, Nabi yang Rahîm, Nabi yang punya misi rahmatan lil 'alamîn. Nabi yang punya prinsip " Buat mudah jangan buat sulit!". "Gembirakan jangan kau takuttakuti”. "Dekati! Jangan buat lari!". "Yassirû wa lâ Tu’assirû!", "Bassyirû wa lâ tundzirû!”.

\section{Pemaknaan Bidah yang Optimis}

Bidah dengan pengertian membuat sesuatu yang baru, hemat penulis harus dimaknai dengan sikap yang positif-optimis, asalkan sesuatu yang baru itu diorientasikan kepada kebaikan dan kemaslahatan. Hal ini sebagaimana prinsip dasar agama Islam, yang menjadi alasan diutusnya Nabi Muhammad ke dunia ini: "wa mâ arsalnâka illa rahmatan lil'alamîn" (Tidaklah Aku mengutus engkau (Muhammad), kecuali untuk menjadi rahmat bagi semesta alam).

Sesuatu yang baru itu merupakan hasil kreasi dan inovasi dari manusia, selaku makhluk yang berkali-kali dipuji Allah sebagai makhluk yang paling sempurna ${ }^{45}$. Kesempurnaan manusia ini bukan pada bentuk fisik, tapi karena potensi akalnya hingga mampu menyingkap berbagai kebesaran Allah yang terhampar di alam raya. Untuk menyingkap berbagai kebesaran Allah yang kemudian kumpulan berbagai ketentuan teorinya menjadi ilmu pengetahuan ini membutuhkan kreasi dan inovasi. Berbagai kreasi dan inovasi jugalah yang membuat seorang manusia dihargai dan disegani oleh sesamanya, dan bahkan oleh makhluk lain ${ }^{46}$. Karenanya, pendapat yang me-

${ }^{44}$ Diriwayatkan oleh Imâm Ahnmâd dan Abû Dawûd.

45 Misalnya saja terlihat dalam Firman Allah: Q.S. At-Tîn [95]: 4, Q. S: Al-Baqarah [2]: 30-34

46 Jin dan malaikat selaku makhluk yang diciptakan lebih dulu dari manusiapun disuruh sujud (hormat) kepada Adam 
ngatakan semua bidah itu sesat, kiranya perlu dipikirkan ulang.

Dalam sejarah Islam, kreasi dan inovasi berkali-kali mengantarkan umat Islam menuju puncak kejayaan hingga disegani oleh umat dan bangsa lain. Sebut saja kreasi dan inovasi nabi Muhammad dalam mengajak masyarakat Arab pada prinsip ketauhidan dan menuju puncak kemanusiaannya. Kreasi dan inovasi para sahabat dalam membukukan Alquran dan meriwayatkan hadis. Kreasi dan inovasi para tabiin khususnya pada masa Abbasiyah yang sangat gandrung akan ilmu pengetahuan, hingga memimpin peradaban dunia misalnya dengan membuat baitul hikmah (masa khalifah Al-Makmun), hingga banyak melahirkan para intelektual kenamaan yang namanya masih diabadikan hingga sekarang, seperti Ibnu Sina, Ibnu Thufail, Al-Kindi, Al-Farabi. Kreasi dan inovasi para ulama yang melahirkan berbagai disiplin ilmu seperti Fiqih dengan penemuan penting al-ahkâm al-syar'iyyah al-khamsah (lima hukum syariat), ilmu tasawuf, ilmu hadis, ilmu tauhid, dan berbagai disiplin ilmu keagamaan lainnya yang belum ada pada masa nabi.

Dalam konteks Indonesia, kita juga masih mengenang dengan manis hasil kreasi dan inovasi Walisongo yang dengan pendekatan sosial budaya, mampu mengislamkan tanah Jawa dan Nusantara dengan damai, penuh harmoni, hampir tanpa pertumpahan darah sama sekali, padahal masyarakat Jawa pada waktu itu sudah memiliki sistem keyakinan yang mapan melalui agama Hindu-Budha, sebagai titik lanjutan dari kepercayaan animisme dan dinamisme yang prinsipprinsipnya hampir sama dengan Hindu-Budha.

Kalau kata kullu dalam hadis kullu bid'atin dhalâlah diartikan seluruh bidah secara mutlak sebagai sesat, maka para sahabat juga telah melakukan dosa secara kolektif (bersama). Hal ini dikarenakan para sahabat banyak melakukan kreasi dan inovasi yang belum ada pada masa Rasul. Misalnya saja sahabat Umar yang melaksanakan salat tarawih secara berjamaah sepanjang malam Ramadhan dengan dipimpin satu orang imam. Sahabat Usman yang membukukan Alquran dalam satu mushaf (yang disetujui oleh sahabat-sahabat yang lain). Sahabat Umar yang tidak membagi habis harta rampasan perang kepada para tentara,

sebagai manusia pertama. Lihat Q.S Al-Baqarah [2]: 34 tapi tetap memberikan garapan kepada para petani setempat namun dikenakan pajak (yang disetujui oleh sahabat-sahabat yang lain). Sahabat Umar yang tidak memotong tangan pencuri yang setelah diselidiki pencuri itu berasal dari kalangan dhuafa dan melakukan aksi pencurian karena terpaksa kelaparan (yang disetujui oleh sahabat-sahabat yang lain). Sahabat-sahabat Nabi dikenal sebagai orang-orang yang taat, beriman dan bertakwa kepada Allah Swt. Bahkan, diantara mereka ada yang sudah dijamin penjadi penghuni surga. Oleh karena itu, tidak mungkin kalau para sahabat Nabi Saw tidak mengetahui, apalagi tidak mengindahkan larangan pada hadis tersebut.

Jika kita sepakat bahwa umat manusia khususnya kalangan muslim diperintahkan untuk mengejewantahkan berbagai sifat mulia Allah yang tercantum dalam asmâ'ul husna, maka salah satu sifat Allah yakni yang Maha Kreatif dan Inovatif (al-badi'), dan Maha Pencipta. Sifat Allah tersebut layak menginspirasi kita untuk berkreasi dan berinovasi bagi kemaslahatan umat manusia secara keseluruhan, sebagaimana prinsip dasar diturunkannya agama Islam dan diutusnya nabi Muhammad, yakni rahmatan lil'âlamîn.

Dengan demikian, bidah yang baik (hasanah), yang diorientasikan bagi kemaslahatan dan kesejahteraan umat manusia bahkan alam raya sebagaimana prinsip agama Islam yang sudah disebutkan diatas, merupakan pintu kreatifitas dan inovasi umat Islam, yang berkali-kali Allah perintahkan dalam Alquran.

\section{Reinterpretasi Konsep Bidah Menuju Islam Transformatif}

Memaknai terminologi bidah dengan semangat yang positif dan optimis dapat digunakan sebagai pintu untuk mendorong terwujudnya Islam transformatif. Misi menegakkan nilai-nilai kemanusiaan dan keadilan sosial tidak mungkin terwujud apabila memaknai agama secara verbal. Dengan demikian, untuk mewujudkan Islam transformatif, harus digunakan kerangka berfikir filosofis untuk menemukan tujuan dasar (ultimate goal) diturunkannya risalah kewahyuan kepada Nabi Muhammad. Dengan kerangka berfikir filosofis dan menemukan tujuan dasar diutusnya Nabi Muhammad, maka tidak akan ditemukan paradoks antara satu ajaran (ayat) dengan ajaran lainnya sebagaimana yang sering kita lihat, tetapi sejatinya 
semua ayat tersebut memiliki tujuan dasar yang sama meskipun dalam konteks yang berbeda.

Menurut Ibn al-Qayyîm al-jawziyyah, syariat yang menjadi simbol hukum Islam harus diarahkan pada aspek kemaslahatan. Sehingga setiap masalah yang keluar dari keadilan menuju kecurangan, dari kasih sayang menuju permusuhan, dari maslahat menuju kerusakan, dan dari kebijakan menuju kesewenang-wenangan, maka bukanlah syariat. ${ }^{47}$. Selain itu, Izzudîn Ibn Abd al-Salâm juga mengatakan, bahwa segala pembebanan hukum Islam harus difokuskan atau dikembalikan untuk kemaslahatan umat manusia, baik di dunia maupun di akhirat. ${ }^{48}$

Abdurrahman Mas'ud yang nampaknya terinspirasi dari Al-Ghazâlî menambahkan, bahwa nilai dasar ajaran agama adalah nilai-nilai Islam al-'adala (keadilan), al-musâwah (egalitarian), asyûrâ (musyawarah), dan al-hurryatul Ikhtiyar (kebebasan memilih dalam konteks hifdzul mâl atau perlindungan harta, hifdzul nafs (perlindungan jiwa), hifdzul dîn (perlindungan agama), hifdzul 'aql (perlindungan akal), dan hifdzul nazl (perlindungan keturunan). ${ }^{49}$

Menggunakan kerangka berfikir filosofis dalam memahami doktrin agama, salah satunya melahirkan wacana Islam tansformatif yang digagas oleh Moeslim Abdurrahman. Menurut Mansour Fakih, Islam transformatif diarahkan untuk melawan segala bentuk ketidakadilan, seperti eksploitasi ekonomi, penindasan politik, dominasi budaya dominasi gender, penindasan warna kulit dengan segala bentuknya ${ }^{50}$. Misi Islam transformatif diatas tidak mungkin dapat terwujud apabila memaknai ajaran agama secara verbal dan mengindahkan pencarian terhadap tujuan dasar diturunkannya wahyu itu sendiri.

Pencarian terhadap tujuan dasar diturunkannya agama juga diharapkan mampu menjawab berbagai kritikan terhadap agama sebagaimana yang disebutkan M. Zainuddin, bahwa dalam kehidupan sehari-hari, pemeluk agama seringkali terjebak kepada sifat individualis dan hanya hlm. 3

47 Ibn al-Qayyim al-jawziyyah, l'lâm al-Muwaqqi'în, juz III,

\footnotetext{
48 Izzudin Ibn Abd al-Salam, Qawa'id al-Ahkâm fî Mashalih al-An'am (Beirut: Dar al-jil, tanpa tahun), juz II h. 72

${ }^{49}$ Lihat Abdurrahman Mas'ud, Menggagas Format Pendidikan Nondikotomik, (Gama Media: Yogyakarta, 2002), h. 134

50 Mansour Fakih, Teologi kaum Tertindas..., h. 203
}

terfokus kepada kehidupan beragamanya saja, melalui doktrin suci, berbagai ritual agama dan lain-lain, sehingga abai terhadap realitas sosial dimana dia hidup ${ }^{51}$.

Berkaitan dengan konsep bidah, yang seringkali menjadi batu sandungan bagi kaum Muslim dalam memecahkan problem sosial yang ada di sekitarnya, maka diperlukan re interpretasi mengenai konsep bidah. Dalam hal ini diperlukan kerangka berfikir filosofis mengenai tujuan diturunkannya wahyu kepada nabi Muhammad, untuk selanjutnya dikaitkan dengan konsep bidah yang sesuai dengan tujuan dasar keislaman diatas.

Berkaitan dengan itu, maka dalam konsep bidah pun harus dikaitkan dengan garis yang lurus untuk menegakkan prinsip-prinsip kemanusiaan sebagimana disebutkan diatas. Sehingga konsep bidah bukannya menjadi beban sejarah, tapi justru mendukung gagasan islam transformatif sebagaimana yang diusung oleh Moeslim Abdurrahman.

Selain itu, kata al-Badi' juga merupakan salah satu asma Allah, sebagai pencipta segala sesuatu yang baru dan tidak ada contoh sebelumnya. Dialah pencipta yang pertama sebelum segala sesuatu ada. Dialah Allah, pencipta yang mengadaadakan sesuatu tanpa contoh terdahulu (mitsal sabiq) ${ }^{52}$. Dengan demikian, jika kaum Muslim diperintahkan ntuk meneladani sifat mulia Allah, maka salah satu sifatnya yakni al-Badi', seharusnya menjadi perhatian seluruh umat Muslim untuk mengerahkan segenap kemampuan yang dimiliki dalam mengembangkan kreatifitas dan inovasi.

Oleh sebab itu, penggunaan konsep bidah yang dimaknai dengan negatif atau pesimis, yakni dengan melarang umat Muslim untuk melakukan semua bentuk bidah (sesuatu yang baru diadakan), merupakan contoh pemahaman keislaman yang tidak menggunakan kerangka berfikir filosofis dalam memahami doktrin agama, sehingga tidak ada upaya untuk memahami tujuan dasar diturunkannya Alquran, dan diutusnya nabi Muhammad Saw. Sebaliknya, dengan menggunakan paradigma berfikir filosofis dari tujuan dasar diturunkannya Alquran dan sunah, dan dimaknai secara kontekstual, maka kesan pertentangan tersebut tidak akan ditemukan.

\footnotetext{
${ }^{51}$ M. Zainuddin, "Plurality of Religion..., h. 154

52 Mujiddu al-Din Abu al-Sa'adat bin Muhammad al-Jaziri ibnu al-Atsir, al-Nihâyah..., h. 106
} 


\section{Penutup}

Dari paparan diatas dapat disimpulkan bahwa konsep Islam transformatif bertujuan untuk menegakkan nilai-nilai kemanusiaan dan keadilan sosial sesuai dengan dasar diturunkannya agama. Salah satu upaya untuk mewujudkan tujuan dasar sesuai dengan konsep Islam transformatif tersebut adalah dengan melakukan reinterprestasi konsep bidah. Melalui pemahaman terhadap doktrin yang didasarkan secara filosofis dan dimaknai secara kontekstual, maka dapat menghilangkan pertentangan antara satu ajaran (doktrin) dengan ajaran lainnya. Dengan demikian, bidah tidak lagi menjadi beban sejarah yang menghalangi kreatifitas dan inovasi umat Islam, tapi justru menjadi pendorong untuk menemukan berbagai terobosan brilian dalam memecahkan berbagai problem sosial masyarakat.

\section{Pustaka Acuan}

Abdurrahman, Moeslim, Islam Sebagai Kritik Sosial, Jakarta: Erlangga, 2003. , Islam Transformatif, Jakarta: Pustaka Firdaus, 1997. , Islam yang memihak, PT LKiS Pelangi Aksara, 2005.

Abdussalam, Abu Muhammad 'Izudin bin, Qawa'id al-Ahkâm fî Mashalih al-An'âm, Beirut: Dar alKutub al-Ilmiyah, tt.

Abdussomad, Muhyiddin, Fiqh Tradisionalis, Jawaban Pelbagai Persoalan Keagamaan Sehari-hari, Malang: Pustaka Bayan kerjasama dengan PP Nurul Islam Jember 2005.

Anwar, M. Syafi'i, Pemikiran dan Aksi Islam Indonesia, Jakarta: Paramadina, 1995.

Atsir, Mujiddu al-Dîn Abu al-Sa'adat bin Muhammad al-Jaziri ibnu al-, al-Nihâyah fî Gharib al-Hadits wa al-atsar, Muassasah isma'iliyan, $1367 \mathrm{H}$, Juz 1.

Baihaqi, Al-, manaqib al-Syafi'i, (Tahqiq) Al-Sayyid Ahmad Shaqr, Al-Qahirah: dar al-Turats, tt.

Baqiry, Syeikh Ja'far Muhammad Ali al-, Al-Bidah, Rabithah al-Tsaqofah wa al-'alaqat al-Islamiyah 1996.

Bukhari, Imam, kitab salat tarawih, bab fadhli man qâma Ramadhân, juz. 3 .

Fakih, Mansour, Teologi kaum Tertindas, dalam spiritualitas Baru: Agama dan Aspirasi Rakyat, Yogyakarta: Dian 1994.

Goodman, George Ritzer dan Douglas J., Teori Sosiologi Modern, Terj. Aliman, Jakarta: Kencana, 2007, Cet. ke-4
Hidayat, Komaruddin, "The Failures of Social Religious Roles" in Dialogue of Muslim Scholars to Realize One Religious Community, Jakarta: UGM Yogyakarta-IFIS, 2010.

Jawziyyah, Ibn al-Qayyim al-, I'lâm al-Muwaqqi'în, juz III.

Jaziri, Muhammad Ibnu al-Atsir al-, Jamî’ al-Ushûl fî Ahadits al-Rasul, Beirut: dar al-Fikr, 1983, Juz. 1.

Maghfur, dkk, Islam Transformatif. Risalah kerja Intelektual Organik, Pekalongan: STAIN Pekalongan Press, 2012.

Mas'ud, Abdurrahman, Menggagas Format Pendidikan Nondikotomik, Gama Media: Yogyakarta, 2002.

Muhammad, Abu, 'Izzu al-Din bin Abdussalam, Qawâ'id al-ahkâm fîmashalih al-An'âm, Beirut: Dar al-Kutub al-Ilmiyah, tt, Juz 1.

Muslim, Imam, kitab shalat al-mushafirîn, bab altaghrîb fî qiyîm Ramadhân, juz. 1.

Rahman, Budhy Munawar, Islam Pluralis: Wacana Kesetaraan Kaum Beriman, Jakarta:Paramadina, 2001.

Ridwan, Dadan, “Model Alternatif Pendidikan Islam Transformatif; Studi Nilai-nilai Pendidikan Islam dalam Tradisi Ambengan pada Peringatan Hari Besar Islam di Desa Brunorejo Purworejo" Jurnal Millah Vol. XIV No. 2 Februari 2015.

Sahibani, Abdul Qayyum Muhammad As- , Mengapa anda menolak bidah hasanah?, Solo: At-Tibyan, 2003.

Salam, Izzudin Ibn Abd al-, Qawa'id al-Ahkâm fî Mashalih al-An'am, Beirut: Dar al-jil, tanpa tahun, juz II.

Sumarna, Cecep, Revolusi Peradaban; Usaha Mencari Tuhan alam Batang Tubuh IImu, Bandung: Sae, 2008.

Supani, "Kajian Terhadap Dalil dan Argumen Pendukung Serta Penolak Adanya Bidah Hasanah", Jurnal Penelitian Agama Vol. 9 No.2, 2008.

Suseno, Frans Magnis, Pemikiran Karl Marx: Dari Sosialisme Utopis ke Perselisihan Revisionosme, Jakarta: Gramedia, 1999.

Syaukani, Muhammad bi Ali bin Muhammad al-, Irsyadul Fuhul, Beirut: Dar al-Fikr, 1992, Juz I.

Wahid, Abdurahman, Islam dan Militerisme Dalam Lintas Sejarah, dalam Muslim di Tengah Pergumulan,Jakarta: Lappenas, 1981.

Zainuddin, $M$, "Plurality of Religion Future Challenges of Religion and Democracy in Indonesia," Journal of Indonesian Islam, Vol. 09, No. 02, Desember 2015. 